\title{
GAYA KEPEMIMPINAN TRANSFORMASIONAL, ORIENTASI PASAR DAN KUALITAS PELAYANAN TERHADAP KINERJA PDAM TIRTA KHATULISTIWA PONTIANAK KALIMANTAN BARAT
}

\author{
Nur Afifah \\ afifahnur_fe@yahoo.com \\ Jurusan Manajemen Fakultas Ekonomi dan Bisnis Universitas Tanjungpura Pontianak
}

\begin{abstract}
The public sector operates in an open system with a complex environment and turbulence as well as customers are increasingly demanding. Understanding customer needs and creating value for the customer is very important for the public sector organizations including for the PDAM. The leadership has an important role in determining the future of the organization and creating public value. Therefore, management must be able to develop a strategy based on the vision and mission as well as its implementation in order to achieve the objectives of the company. The purpose of this study is to explore the effect of transformational leadership style towards market orientation, service quality and its impact on the performance of PDAM Tirta Khatulistiwa Pontianak. Total respondents are 100 employees represented by each department which corresponding to the tasks of customer service by using purposive sampling method. The analytical tool used is Structural Equation Modeling (SEM). The results showed that transformational leadership style affects the performance of PDAM Tirta Khatulistiwa Pontianak, transformational leadership style effect on market orientation, but the leadership style has no effect on the service quality. Furthermore, market orientation has no effect on the service quality while market orientation has affects on the performance of PDAM Tirta Khatulistiwa Pontianak. Then the service quality affects the performance of PDAM Tirta Khatulistiwa Pontianak.
\end{abstract}

Key words: transformational leadership style, market orientation, service quality, performance of PDAM.

\begin{abstract}
ABSTRAK
Sektor publik beroperasi pada sistem yang terbuka dengan lingkungan yang komplek dan turbulence serta pelanggan yang semakin demanding. Memahami kebutuhan pelanggan dan menciptakan nilai bagi pelanggan sangat penting bagi organisasi sektor publik termasuk Perusahaan Daerah Air Minum (PDAM). Kepemimpinan memiliki peran penting dalam menentukan masa depan organisasi dan menciptakan publik value, oleh karena itu pimpinan harus mampu mengembangkan strategi berdasarkan visi dan misi serta implementasinya untuk mencapai sasaran perusahaan. Tujuan penelitian ini untuk mengeksplorasi pengaruh gaya kepemimpinan transformasional terhadap orientasi pasar, kualitas pelayanan serta dampaknya terhadap kinerja PDAM Tirta Khatulistiwa Pontianak. Jumlah responden 100 karyawan yang diwakili oleh masing-masing bagian yang berhubungan dengan tugas melayani pelanggan, dengan menggunakan metode purposive sampling. Alat analisis yang digunakan Structural Equation Modeling (SEM). Hasil penelitian menunjukkan bahwa, gaya kepemimpinan transformasional berpengaruh pada kinerja PDAM Tirta Khatulistiwa Pontianak, gaya kepemimpinan transformasional berpengaruh pada orientasi pasar, akan tetapi gaya kepemimpinan tidak berpengaruh pada kualitas pelayanan. Selanjutnya orientasi pasar tidak berpengaruh pada kualitas pelayanan sedangkan orientasi pasar berpengaruh pada kinerja PDAM Tirta Khatulistiwa Pontianak. Kemudian kualitas pelayanan berpengaruh pada kinerja PDAM Tirta Khatulistiwa Pontianak.
\end{abstract}

Kata kunci: gaya kepemimpinan transformasional, orientasi pasar, kualitas layanan dan kinerja PDAM. 


\section{PENDAHULUAN}

Industri jasa memiliki peran yang sangat penting dalam perekonomian di suatu negara (Lovelock, 2012), memberikan pelayanan yang berkualitas dalam lingkungan global saat ini dianggap sebagai strategi penting bagi keberhasilan dan kelangsungan hidup suatu organisasi bisnis. Termasuk pada sektor publik, saat ini mendapat tuntutan untuk meningkatkan dan memberikan pelayanan yang berkualitas kepada masyarakat atau pelanggannya (Munhurrun et al., 2010; Caemmerer dan Wilson, 2011). Pemimpin pada sektor publik dituntut untuk dapat melakukan perubahan-perubahan dalam organisasi dan pelayanan publik (Piening, 2013; Voet et al., 2013), serta mengelola sektor public secara efektif (Pandey 2010; Donald et al., 2014). Oleh karena itu orientasi pasar sangat diperlukan dalam sektor publik karena dengan orientasi pasar yang kuat akan menghasilkan nilai pelanggan yang unggul melalui kualitas layanan yang disampaikan kepada pelanggan sehingga berdampak pada kinerja perusahaan (Mahmoud et al., 2010; Gummerus, 2013: Rubina et al., 2016).

Perusahaan Daerah Air Minum (selanjutnya disebut dengan PDAM) merupakan Badan Usaha Milik Daerah yang dimiliki oleh Pemerintah Daerah Kota/ Kabupaten sebagai pemilik modalnya. Sebagai bagian dari organisasi sektor publik, PDAM merupakan entitas bisnis yang memberikan pelayanan umum air bersih kepada pelanggannya. PDAM merupakan sektor publik yang berbentuk quasi non profit organization yang menghasilkan quasi private goods, yaitu menghasilkan barang atau jasa kebutuhan masyarakat yang mana manfaat barang atau jasa tersebut hanya dinikmati secara individual yang membelinya walaupun sebetulnya barang atau jasa tersebut dapat dinikmati semua masyarakat (Fitriyani et al., 2015). Oleh karena itu memberikan pelayanan berkualitas sesuai dengan harapan pelanggan dan berorientasi pada kepuasaan pelanggan merupakan suatu keharusan, karena pelanggan yang puas merupakan salah satu basis bagi kelangsungan hidup dan perkembangan bisnis perusahaan itu sendiri. Dengan demikian tuntutan untuk terus berinovasi dan meningkatkan kerja sama antar bagian untuk dapat menghasilkan keunggulan yang berkelanjutan merupakan suatu keharusan (Beeta et al., 2015). Hal ini dikarenakan semakin pentingnya sektor publik dalam membangun perekonomian bangsa, sehingga dalam pengelolaan manajemen sektor publik tidak boleh hanya berfokus pada apa yang baik dimasa lalu atau bahkan pada apa yang baik hari ini tapi apa yang bisa dilakukan lebih baik di masa depan.

Membangun keunggulan yang berkelanjutan bukan pekerjaan mudah, jika tidak didukung adanya strategi yang jelas dan bisa dijalankan. Untuk itu, agar dapat melaksanakan fungsinya sebagai organisasi sektor publik dituntut untuk dapat mengalokasikan sumber daya strategis yang dimiliki untuk menciptakan public value (Bekkers et al, 2013; Pee dan Kankanhalli. 2015), sumber daya strategis perusahaan adalah teknologi, proses dan prosedur serta pegawai yang dimiliki perusahaan, oleh karena itu pimpinan organisasi harus mampu mengalokasikan sumber daya strategis yang dimilikinya, terutama pegawai layanan (people in services) yang merupakan bagian dari sumber daya yang dimiliki perusahaan untuk langsung berinteraksi dengan pelanggan dalam menyampaikan layanan yang dapat meningkatkan kinerja perusahaan (De Farrias, 2010; Asgari, 2014; Pahi dan Hamid, 2015).

PDAM Tirta Khatulistiwa, merupakan salah satu PDAM yang berada di Pontianak Kalimantan Barat yang memiliki kinerja coorporate dalam kondisi sehat (Penilaian Kinerja PDAM, 2015), walaupun demikian pihak manajemen dituntut untuk senantiasa melakukan perubahan dalam manajemen perusahaan, desain dan pelayanan publik agar dapat melaksanakan fungsi-fungsinya 
dengan baik dan dapat meningkatkan kinerja perusahaan saat ini dan dimasa yang akan datang menjadi PDAM yang mandiri dan berkelanjutan (Sustainable Local Enterprise Performance). Meskipun dalam proses perubahan merupakan tantangan besar bagi PDAM Tirta Khatulistiwa Pontianak karena dalam pengambilan keputusan lebih sulit dikarenakan berhubungan dengan kepentingan stakeholder dengan demikian mempengaruhi kinerja organisasi (Isett et al., 2012; Fraczkiewicz dan Symaniec, 2013; Szymaniec Mlicka, 2014).

Kepemimpinan memiliki peran penting dalam menentukan masa depan bisnis. Penelitian tentang gaya kepemimpinan dan dampaknya terhadap organisasi sangat menarik untuk dilakukan terutama pada PDAM, dikarenakan PDAM berada pada lingkungan dengan sistem terbuka yang komplek dan turbulence serta pelanggan yang semakin demanding. Oleh karena itu diperlukan suatu gaya kepemimpinan yang dapat menciptakan inspirasi kepada bawahannya. Gaya kepemimpinan transformasional memiliki kecenderungan untuk meningkatkan kinerja organisasi dikarena kan gaya kepemimpinan yang menginspirasi semua orang dalam organisasi, selalu menanamkan sikap positif dan menginspirasi pegawai sehingga kepemimpinan transformational memiliki dampak positif pada kinerja organisasi (Peris dan Namusonge, 2012; Donald et al., 2014; Ozer dan Tinaztepe, 2014; Birasnav, 2014; Chiun et al., 2015), dengan demikian kinerja organisasi tergantung pada pimpinan organisasi dalam menetapkan misi dan visi serta keberadaannya di pasar.

Untuk mengidentifikasi strategi yang tepat agar misi dan visi PDAM Tirta Khatulistiwa Pontianak dapat tercapai, salah satu taktik yang harus dilakukan adalah orientasi pasar, dimana organisasi berusaha untuk mengidentifikasi dan memenuhi kebutuhan pelanggan. Akan tetapi untuk itu diperlukan pimpinan yang berkarakter transformasional. Beberapa hasil penelitian menyatakan bahwa gaya kepemimpinan transformasional dapat mempengaruhi orientasi pasar (Theodosiou et al., 2012; Pinho et al, 2014; Chiun et al., 2015). Selain mempengaruhi orientasi pasar, pemimpin transformational dapat mempengaruhi pegawai untuk menyampaikan pelayanan terbaik kepada pelanggan (Rowold, 2011; Wright et al., 2012; Pahi dan Hamid, 2015).

Orientasi pasar adalah budaya organisasi yang menghasilkan perilaku yang diperlukan untuk menciptakan value-in use kepada pelanggan dan peningkatan kinerja. Orientasi pasar pada sektor publik sangat penting dikarenakan dengan orientasi pasar, PDAM akan dapat menciptakan dan memberikan pelayanan sesuai kebutuhan pelanggan. Menurut (Polat dan Mutlu, 2012), Orientasi pasar dipandang sebagai kemampuan perusahaan yang sangat berharga, langka, dan yang tidak dapat dengan mudah ditiru, dengan penekanan menempatkan pelanggan di pusat strategi dan operasi perusahaan. Beberapa hasil penelitian menyatakan bahwa orientasi pasar dapat mempengaruhi kinerja perusahaan (Ahmad, 2011; Eris dan Ozmen, 2012; Wilson, et al., 2014; Shehu dan Mahmood, 2014; Rubina et al., 2016; Zafar et al., 2016), sehingga perusahaan yang berorientasi pasar akan lebih siap dalam memberikan pelayanan yang berkualitas dan bernilai unggul karena dapat menciptakan kepuasan pelanggan dan orientasi pelanggan (Faryabi et al., 2011; Ramayah et al, 2011; Chin et al., 2013), oleh karena itu orientasi pasar berpengaruh positif terhadap kualitas pelayanan (Ramayah et al., 2011; Hojati et al., 2012; Chin et al., 2013, Pahi dan Hamid, 2015).

Memberikan pelayanan yang berkualitas adalah bagian dari strategi yang sangat penting dalam era global karena dapat meningkatkan keberhasilan dan kelangsungan hidup organisasi termasuk sektor publik, oleh karena itu memberikan pelayanan yang berkualitas kepada masyarakat atau pelanggan merupakan bagian dari 
tanggung jawab PDAM dalam menjalankan fungsi-fungsinya sebagai sektor publik. Beberapa hasil penelitian menyatakan bahwa kualitas pelayanan dapat mempengaruhi kinerja perusahaan (Lopez, 2010; Kersten dan Koch, 2010; Shekarchizadeh et al., 2011; Chiun et al., 2015).

Berdasarkan penjelasan dalam uraian di atas, maka dalam penelitian ini memiliki beberapa tujuan yaitu; untuk mengeksplorasi pengaruh gaya kepemimpinan transformasional terhadap orientasi pasar, kualitas pelayanan serta dampaknya terhadap kinerja PDAM Tirta Khatulistiwa Pontianak. Selain itu penelitian tentang gaya kepemimpinan transformasional, oreintasi pasar, kualitas pelayanan terhadap kinerja PDAM masih sedikit dilakukan kajian. Beberapa penelitian yang sudah dilakukan dalam sektor publik, diantaranya: penelitian tentang studi tentang kualitas pelayanan pada sektor publik di Republik Turki Siprus Utara (Lyikal dan Celebi, 2016), studi pada sektor publik jasa keuangan di Malaysia (Chiun et al., 2015), studi tentang orientasi pasar pada sektor publik Departemen Militer Negara Sao Paulo (Mainardes dan Cerqueira, 2014), studi tentang kepemimpinan dalam sektor publik (Donald et al., 2014), studi yang berbeda di rumah sakit di Pakistan (Irfan dan Ijaz 2011; Nisa et al., 2012), studi tentang gaya kepemimpinan pada sektor publik di Negara Kenya (Peris dan Namusonge, 2012), serta studi tentang kualitas pelayanan pada sektor publik (Munhurrun et al., 2010).

Penelitian ini sangat penting untuk mengeksplor bagaimana pengaruh gaya kepemimpinan transformasional terhadap orientasi pasar, kualitas pelayanan dan dampaknya terhadap kinerja PDAM Tirta Khatulistiwa Pontianak Kalimantan Barat. Ada beberapa hal yang menjadi dasar pertimbangan diantaranya: Berdasarkan penilaian kinerja yang diselenggarakan oleh BPKP wilayah Kalimantan Barat tahun 2015, menunjukkan kinerja corporate mengalami perkembangan yang semakin membaik bahkan memiliki kinerja dalam kategori sehat, dengan capaian layanan pelanggan sebesar $85 \%$ dari jumlah penduduk di wilayah Pontianak, selain itu merupakan satusatunya PDAM di wilayah Kalimantan Barat dengan kondisi sehat. Adanya capaiancapaian tersebut apakah PDAM Tirta Khatulistiwa sudah memberikan pelayanan yang terbaik kepada pelanggannya dan berorintasi pasar, selain itu karena PDAM merupakan sektor publik yang mendapat tuntutan untuk dapat melakukan perubahan dalam organisasi dan pelayanan publik.

\section{TINJAUAN TEORETIS}

\section{Gaya Kepemimpinan Transformasional.}

Pada saat ini, mayoritas organisasi berupaya untuk mencapai keunggulan yang berbeda dengan perusahaan lain yang sejenis, baik dalam hal sumber daya manusia, teknologi dan proses organisasi. Hal ini dilakukan dalam rangka mencapai visi dan misi organisasi. Selain itu terlepas dari pencapain visi dan misi, sebuah organisasi harus memenuhi kewajibannya untuk mengembalikan investasi yang di berikan oleh pemerintah atau pemilik modal, begitu juga dengan PDAM. Memiliki tuntutan untuk dapat mengembalikan investasi yang sudah diberikan oleh pemerintah daerah maupun pemerintah pusat dengan cara memiliki kinerja yang unggul.

Studi tentang kepemimpinan merupakan suatu kerjasama antara atasan dan bawahan dimana seorang pemimpin akan memperhatikan masukan dan pendapat dari bawahannya untuk mencapai tujuan organisasi (Yukl, 2010), oleh karena itu kepemimpinan merupakan elemen yang sangat penting dalam memformulasikan value market orientation pada suatu organisasi dalam pelaksanaan sehari-hari. Pemimpin menjadi salah satu faktor penentu dalam mencapai visi dan misi perusahaan (Pandey, 2010; Crook et al., 2011; Chiun et al., 2015), karena pemimpin menjadi unsur penting dalam keberhasilan suatu organisasi. Dengan demikian kinerja organisasi ter- 
gantung pada pemimpinnya dalam menetapkan misi dan visi serta keberadaannya di pasar.

Organisasi publik sering kali menerapkan perubahan-perubahan dalam organisasi, desain dan pelayanan publik (Voet et al., 2013), dikarenakan sektor publik beroperasi pada sistem yang terbuka dengan lingkungan yang komplek dan turbulence serta pelanggan yang semakin demanding, oleh karena itu seorang pemimpin harus benar-benar memahami berbagai perubahan dalam lingkungan bisnis termasuk keinginan pelanggan yang kemudian memikirkan bagaimana perusahaan memenuhi keinginan pelanggan. Pelaksanaan perubahan organisasi tersebut merupakan tantangan besar bagi organisasi sektor publik (Piening, 2013; Voet et al., 2013), oleh karena itu gaya kepemimpinan merupakan bagian yang dapat menciptakan suatu kondisi yang ada pada organisasi. Kondisi yang komplek seperti itu memerlukan gaya kepemimpinan transformasional (Garcia et al., 2012; Belle 2012, Grant, 2012; Oberfield, 2012, Donald et al., 2014), dikarenakan gaya kepemimpinan transformasional dapat meningkatkan produktivitas dan penilaian kinerja individu, dengan kata lain pemimpin transformasional selalu berusaha untuk meningkatkan motivasi, inovasi dan meningkatkan prestasi.

Gaya kepemimpinan transformasional memiliki kecenderungan untuk meningkatkan kinerja organisasi dikarenakan gaya kepemimpinan yang menginspirasi semua orang dalam organisasi, selalu menanamkan sikap positif dan menginspirasi pegawai sehingga kepemimpinan transformasional memiliki dampak positif pada kinerja organisasi (Peris dan Namusonge, 2012; Donald et al., 2014; Ozer dan Tinaztepe, 2014; Birasnav, 2014; Chiun et al., 2015).

Menurut Rowold (2011), gaya kepemimpinan transformasional merupakan salah satu gaya kepemimpinan yang penting. Hal ini dikarenakan gaya kepemimpinan transformasional memiliki kemampuan untuk mempengaruhi bawahan untuk mencapai kinerja yang luar biasa. Dengan demikian kepemimpinan transformasional adalah kepemimpinan yang memiliki visi ke depan dan mampu mengidentifikasi perubahan lingkungan serta mampu mentransformasikan perubahan tersebut ke dalam organisasi, mempelopori perubahan dan memberikan motivasi, inspirasi kepada individu-individu karyawan untuk kreatif dan inovatif serta membangun team work yang solid, membawa pembaharuan dalam etos kerja dan kinerja yang optimal, berani dan bertanggung jawab memimpin dan mengendalikan organisasi (Schneider dan George, 2011; Moynihan et al., 2012; Belle 2012). Selain mempengaruhi kinerja organisasi, beberapa hasil penelitian menyatakan bahwa gaya kepemimpinan transformasional dapat mempengaruhi orientasi pasar (Theodosiou et al., 2012; Pinho et al, 2014; Chiun et al., Chiun et al., 2015), serta dapat mempengaruhi pegawai untuk menyampaikan pelayanan terbaik kepada pelanggan (Rowold, 2011; Wright et al., 2012; Pahi dan Hamid, 2015; Lyical dan Celebi, 2016).

Meskipun ada beberapa perdebatan tentang komponen yang mendasari gaya kepemimpinan transformasional, tetapi ada kesepakatan bersama bahwa gaya kepemimpinan transformasional adalah dimana para pemimpin mampu mengubah sikap bawahannya dan memiliki komitmen untuk melaksanakan misi organisasi secara konsisten. Konsep kepemimpinan transformasional dikembangkan oleh Bass dan Avolio, dengan empat dimensi diantaranya; (1) Inspirational motivation, (2) Idealized influence, (3) Intellectual stimulation, dan (4) Individual consideration.

Variabel gaya kepemimpinan transformasional dalam penelitian ini menggunakan empat dimensi yang akan dijadikan indikator dalam studi ini (Oberfield 2012; Wright, 2012; Donald et al., 2014), diantaranya: (1) idealized influence (Idealisasi pengaruh), dimana pemimpin memiliki 
perilaku yang menghasilkan rasa hormat (respect) dan rasa percaya diri (trust) dari orang-orang yang dipimpinnya, (2) inspirasional motivation (Motivasi inspirasional), dimana pemimpin meningkatkan kesadaran dari para pegawai mengenai visi dan misi organisasi serta mendorong untuk memahami dan komitmen terhadap visi adalah fase kunci dari gaya kepemimpinan transformasional, (3) intellectual stimulation (Stimulasi intelektual), dimana pemimpin mendemonstrasikan tipe kepimpinan yang senantiasa menggali ide-ide baru dan solusi yang kreatif dari orang-orang yang dipimpinnya dan (4) individual consideration (Konsiderasi pribadi), berkaitan dengan perilaku kepemimpinan transformasional yang fundamental dari memperlakukan individu sebagai kontribusi penting di tempat kerja.

Adanya beberapa hasil penelitian yang dijelaskan diatas, maka dalam penelitian ini dapat disusun hipotesa sebagai berikut:

$\mathrm{H}_{1}$ : Gaya kepemimpinan transformasional berpengaruh positif terhadap kinerja PDAM Tirta Khatulistiwa Pontianak.

$\mathrm{H}_{2}$ : Gaya kepemimpinan transformasional berpengaruh positif terhadap orientasi pasar.

$\mathrm{H}_{3}$ : Gaya kepemimpinan transformasional berpengaruh positif terhadap kualitas pelayanan.

\section{Orientasi Pasar.}

Orientasi pasar sangat diperlukan oleh perusahaan agar dapat meningkatkan daya saing dan daya jual suatu organisasi pada pelanggan. Organisasi yang berorientasi pasar akan mencari sumber informasi yang ada di lingkungan eksternal untuk menjalin hubungan pelanggan dan memahami kebutuhan dan keinginan pelanggan, sehingga dengan berorientasi pasar perusahaan akan selalu berusaha untuk meningkatkan kepuasan pelanggan dengan memenuhi harapan-harapan pelanggan terhadap produk yang dihasilkan oleh Perusahaan. Demikian juga dengan PDAM Tirta Khatulistiwa Pontianak.
Konsep orientasi pasar dikategorikan menjadi dua pendekatan, yaitu pendekatan perilaku dan pendekatan budaya. Pendekatan perilaku mengatakan bahwa orientasi pasar merupakan serangkaian kegiatan yang diarahkan untuk membuat pelanggan senang (Zafar et al., 2016), sedangkan pendekatan budaya mengatakan bahwa orientasi pasar merupakan serangkaian kegiatan yang menekankan pada nilai-nilai bersama perusahaan dan menganggap bahwa pelanggan adalah prioritas pertama. Menurut (Polat dan Mutlu, 2012), orientasi pasar dipandang sebagai kemampuan perusahaan yang sangat berharga, langka, dan yang tidak dapat dengan mudah ditiru, dengan penekanan menempatkan pelanggan di pusat strategi dan operasi perusahaan, oleh karena itu, orientasi pasar merupakan alat yang penting untuk mencapai keunggulan kompetitif dan meningkatkan kinerja organisasi, sehingga studi tentang orientasi pasar sangat menarik untuk dilakukan.

Konsep orientasi pasar sangat penting dilakukan oleh PDAM dalam rangka menciptakan public value kepada masayarakat, hal ini dikarenakan dengan orientasi pasar perusahaan akan melakukan penyesuaian terhadap sumber daya yang dimiliki dan proses bisnisnya dalam rangka memenuhi kebutuhan pelanggan serta membantu menilai kendala dan peluang yang diciptakan oleh lingkungan (Kumar et al., 2011), dengan demikian perhatian organisasi terpusat pada kebutuhan pelanggan (Chung et al., 2011), sehingga dengan orientasi pasar yang kuat dapat berpengaruh terhadap kinerja perusahaan. Beberapa hasil penelitian menyatakan bahwa orientasi pasar dapat mempengaruhi kinerja perusahaan (Mahmoud et al., 2010; Ahmad, 2011; Chin, 2013; Wilson et al., 2014; Shehu dan Mahmood, 2014).

Apalagi adanya pasar bebas mendorong perusahaan daerah untuk berorientasi pasar, selain membuat perusahaan daerah semakin kompetitif, orientasi pasar juga berperan sebagai landasan pengembangan kualitas layanan yang diberikan kepada pelanggan. Orientasi pasar yang kuat akan dapat 
menciptkan public value bagi sektor publik, dikarenakan dengan orientasi pasar akan menyebabkan perusahaan dapat menciptakan nilai terbaik kepada pelanggan melalui produk dan layanannya, dengan demikian akan mengakibatkan kinerja organisasi menjadi lebih baik. Hal ini dikarenakan perusahaan yang berorientasi pasar akan lebih siap dalam memberikan pelayanan yang berkualitas dan bernilai unggul karena dapat menciptakan kepuasan pelanggan dan orientasi pelanggan (Faryabi et al., 2011; Ramayah et al, 2011; Chin et al., 2013), oleh karena itu orientasi pasar berpengaruh positif terhadap kualitas pelayanan (Ramayah et al., 2011; Hojati et al., 2012; Chin et al., 2013; Pahi dan Hamid, 2015).

Dalam penelitian ini menggunakan instrumen pengukuran MARKOR yang dikembangkan oleh Kohli dan Jaworski, yang dimodifikasi sesuai dengan konteks sektor publik (Walker et al., 2011; Protco dan Dornberger 2014), diantaranya; intelligence dissemination, intelligence generation, and responsiveness. Berdasarkan hal tersebut, maka dalam penelitian ini dapat disusun hipotesa sebagai berikut:

$\mathrm{H}_{4}$ : Orientasi pasar berpengaruh positif terhadap kinerja sektor publik (PDAM Tirta Khatulistiwa Pontianak).

$\mathrm{H}_{5}$ : Orientasi pasar berpengaruh positif terhadap kualitas pelayanan.

\section{Kualitas Layanan.}

Industri jasa memiliki peran yang sangat penting dalam perekonomian di suatu negara (Lovelock, 2012). dalam lingkungan yang sangat kompetitif dan global seperti saat ini, memberikan layanan berkualitas dan kompetitif merupakan bagian dari strategi yang sangat penting untuk keberhasilan dan kelangsungan hidup perusahaan (Munhurrun et al., 2010). Begitu juga dengan sektor publik saat ini, ditekankan untuk dapat memberikan layanan yang berkualitas dan menciptakan publik velue (Agbor, 2011; Lykal dan Celebi, 2016).

Kualitas layanan telah menarik banyak perhatian baik dari akademisi maupun dari praktisi dikarenakan pengaruhnya terhadap biaya, kinerja keuangan, kepuasan pelanggan dan retensi pelanggan. Adanya kondisi persaingan yang sangat kompetitif saat ini, kualitas layanan (service quality) secara luas diakui sebagai persyaratan penting dari suatu perusahaan (Voet et al., 2013) bahkan kualitas layanan sebagai salah satu strategi kompetitif yang sangat penting untuk meningkatkan profitabilitas perusahaan dan kelangsungan hidup perusahaan.

Kualitas layanan lebih sulit dievaluasi oleh pelanggan dari pada kualitas barang, dikarenakan penilaian terhadap kualitas layanan tidak hanya didasarkan pada hasil kualitas dari teknik layanan saja tetapi melibatkan proses penyediaan layanan atau kualitas fungsional. Hal ini sejalan dengan pendapat (Lovelock, 2012; Weerawit dan Vinai, 2014) yang menyatakan bahwa persepsi konsumen terhadap kualitas merupakan suatu hal yang sulit dipahami, bahkan pemahaman tentang kualitas sering disalah artikan sebagai sesuatu yang baik, kemewahan, keistimewaan atau sesuatu yang berbobot atau bernilai. Kesulitan dalam menilai kualitas dirasakan lebih berat, dikarenakan persepsi konsumen dalam menilai kualitas sifatnya sangat subyektif, meskipun, kualitas produk baik barang atau jasa akan memberikan kontribusi yang besar terhadap kepuasan pelanggan, pangsa pasar dan return on investmen perusahaan melalui penurunan biaya dan perbaikan produktivitas, serta berpengaruh terhadap loyalitas pelanggan.

Hal ini dikarenakan kualitas layanan merupakan suatu konstruk yang komplek, yang dikaji dalam disiplin pemasaran jasa (Kumasey, 2014). Kualitas layanan digambarkan secara general dan dievaluasi secara menyeluruh dalam jasa atau merupakan evaluasi konsumen dari sejumlah atribut yang terkait. Bahkan dikemukakan bahwa kualitas layanan telah dideskripsikan sebagai multi dimensional konstruk yang dibangun melalui evaluasi terhadap konstruk dari sejumlah atribut yang terkait dengan jasa (Lovelock, 2012; Chang dan 
Horg, 2010; Greenwel et al., 2012). Sebagai konstruk yang kompleks dan paling diinvestigasi pada disiplin ilmu pemasaran, maka pemikiran tentang konsep kualitas layanan terus mengalami perkembangan. Khususnya, kebutuhan terhadap model untuk menilai kualitas layanan yang diberikan oleh perusahaan atau organisasi jasa.

Kualitas pelayanan pada dasarnya sangat penting bagi suatu perusahaan, dikarenakan kualitas pelayanan yang diberikan oleh perusahaan kepada pelanggan dapat menciptakan keuggulan kompetitif. Hal ini dikarenakan kualitas pelayanan yang diberikan oleh perusahaan dapat memenuhi kebutuhan dan keinginan pelanggan. Oleh karena itu PDAM harus berupaya untuk memberikan kualitas pelayanan yang terbaik bagi pelanggannya dikarenakan kualitas pelayanan merupakan persyaratan penting bagi sektor publik untuk selalu meningkatkan pelayanannya kepada pelanggan (Munhurrun, 2010), bahkan kualitas layanan sebagai salah satu strategi kompetitif yang sangat penting untuk meningkatkan profitabilitas perusahaan dan kelangsungan hidup perusahaan. Hasil penelitian (Chiun et al., 2015; Shekarchizadeh et al., 2011; Kersten dan Koch, 2010), menyatakan bahwa kualitas pelayanan dapat mempengaruhi kinerja sektor publik.

Kualias pelayanan dalam penelitian ini, mengembangkan konsep kualitas pelayanan yang dikemukakan oleh Brady dan Cronin (interaction quality, physical environment quality dan outcome quality) serta dimensi SERVQUAL (reliable dan assurance). Hal ini dikarenakan konsep kualitas pelayanan tersebut sangat mendukung penelitian ini karena menggunakan pendekatan relasional yang mewakili aspek operasional pelayanan dari PDAM yaitu $3 \mathrm{~K}$ (kualitas, kuantitas dan kualitas air), sehingga dalam operasional PDAM pegawai layanan dituntut untuk lebih interaktif serta mampu memberikan jaminan kepada pelanggan terhadap kualitas dari produksi air yang dihasilkan.

Indikator kualitas pelayanan dalam penelitian ini (Munhurrum, 2010; Foster
2010; Chang dan Horg, 2010; Greenwel et al., 2012; Afifah et al., 2015), diantaranya adalah; (1) interaction quality (Kualiatas interaksi) adalah kontak yang terjadi pada proses jasa disampaikan dalam pertemuan antara penyedia jasa dan pelanggan, yang merupakan kunci penentu evaluasi pelanggan terhadap kualitas layanan (Lovelock, 2012), (2) physical environment quality (Kualitas lingkungan fisik), menurut (Chang dan Horg, 2010; Greenwel et al., 2012), yaitu sebuah kualitas yang ada di dalam lingkungan di mana proses pelayanan itu terjadi, lingkungan layanan telah dikaitkan dengan lingkungan fisik dari pertemuan layanan atau apa yang telah diperlakukan sebagai service scape, dan, (3) outcome quality (Kualitas hasil akhir) adalah apa yang didapatkan oleh pelanggan, ketika proses produksi jasa dan interaksiinteraksi antara pelanggan dengan penyedia layanan selesai diproduksi. Termasuk ketepatan/kecepatan waktu dalam penyampaian jasa yang merupakan salah satu faktor atau faktor kegagalan jasa, dalam pelayanan PDAM Tirta Khatulistiwa Pontianak dalam hal ini adalah kecepatan proses pelayanan terhadap pelanggan (Proses pemasangan SR, aktif/pasif pelanggan, dan lain-lain) serta kualitas, kuantitas dan kualitas air (3K) yang disalurkan ke pelanggan. Berdasarkan hal tersebut, maka dalam penelitian ini dapat disusun hipotesa sebagai berikut:

$\mathrm{H}_{6}$ : Kualitas pelayanan berpengaruh positif terhadap kinerja sektor publik (PDAM Tirta Khatulistiwa Pontianak).

\section{Kinerja PDAM.}

Pengukuran kinerja perusahaan menjadi topik penting bagi para akademisi dan praktisi mulai tahun 1990. Kinerja organisasi meliputi tiga bidang diantaranya; (1) Kinerja keuangan laba, returnonasset, returnoninvestment, dan lain-lain), (2) Kinerja produk pasar (penjualan, pangsa pasar, dan lain-lain), (3) Pemegang saham (jumlah pemegang saham, nilai tambah ekonomi, dan lain-lain), sedangkan (Ozer dan Tinaztepe, 2014), mendefinisikan kinerja organisasi merupakan salah satu variabel yang digunakan untuk 
mengukur tingkat kinerja perusahaan dalam mencapai tujuan organisasi diantaranya efisiensi dan efektifitas. Akan tetapi indikator kinerja perusahaan yang sering digunakan diantaranya adalah tingkat pertumbuhan laba, tingkat penjualan kembali, ROA dan kinerja secara keseluruhan (Zizlavsky, 2014), atau hanya dari sudut finansial saja. Akan tetapi saat ini penilaian kinerja perusahaan tidak hanya melihat dari sudut keuangan saja, melainkan dilihat dari sudut non keuangan yaitu aspkek pelanggan, aspek sumber daya manusia, aspek bisnis internal dan aspek pertumbuhan bisnis yang diperkenalkan oleh Robert Kaplan dan David Norton yaitu pengukuran kinerja perusahaan yang berbasis Balanced Scorecard (BSC) pada Januari-Februari 1992.

Begitu juga dengan PDAM di Indonesia, berdasarkan Keputusan Menteri Dalam Negeri No: 690-069 Tahun 1992, tentang Pola Petunjuk Teknis Pengelolaan PDAM ditegaskan bahwa PDAM mempunyai tugas pokok pelayanan umum kepada masyarakat, dimana dalam menjalankan fungsinya PDAM diharapkan mampu membiayai dirinya sendiri (self financing) dan harus berusaha mengembangkan tingkat pelayanannya, disamping itu PDAM diharapkan memberikan sumbangan pembangunan kepada PEMDA. Selanjutnya dalam keputusan Menteri Dalam Negeri Nomor 47 Tahun 1999 tentang pedoman penilaian kinerja PDAM dinyatakan bahwa tujuan pendirian PDAM untuk memenuhi pelayanan dan kebutuhan air bersih bagi masyarakat serta sebagai salah satu sumber PAD. Selanjutnya berdasarkan Peraturan Menteri Pekerjaan Umum Pasal 59, Nomor 18/PRT/M/2007 tentang Penyelenggaraan Pengembangan SPAM (BPSPAM), mulai Tahun 2010 dilakukan penilaian kinerja PDAM dengan menggunakan penilaian pada empat aspek diantaranya keuangan, pelayanan, operasional, dan sumber daya manusia yang berbasis Balance Scorecard (BSC). Pelaksanaan penilaian oleh BPKP di setiap Propinsi dengan dilakukan audit setiap tahunnya serta dipublikasi secara nasional dengan tiga peringkat kinerja PDAM seluruh Indonesia, diantaranya kategori sehat, kurang sehat dan sakit. Tujuan penilaian kinerja dilakukan agar sektor publik dapat menjalankan fungsinya yaitu dapat menciptakan public value bagi pelanggan dan stakeholders, selain itu secara jangka panjang dapat menciptakan kinerja PDAM yang mandiri dan berkelanjutan (sustainable local enterprise performance).

Indikator kinerja perusahaan daerah dalam hal ini PDAM, dalam penelitian ini mengacu pada pendapat (Ozer dan Tinaztepe, 2014; Madsen dan Stenheim, 2014) yang meliputi; pertumbuhan jumlah pelanggan, kemampuan pengembangan produk/layanan, profitabiltas perusahaan, komitmen karyawan, dan kepuasan kerja karyawan.

\section{Rerangka Konseptual Penelitian.}

Gaya kepemimpinan transformasional memiliki kecenderungan untuk meningkatkan kinerja organisaisi dikarenakan gaya kepemimpinan yang menginspirasi semua orang dalam organisasi, selalu menanamkan sikap positif dan menginspirasi pegawai sehingga kepemimpinan transformational memiliki dampak positif pada kinerja organisasi (Peris dan Namusonge, 2012; Donald et al., 2014; Ozer dan Tinaztepe, 2014; Birasnav, 2014; Chiun et al., 2015), dengan demikian kinerja organisasi tergantung pada pimpinan organisasi dalam menetapkan misi dan visi serta keberadaannya di pasar. Untuk itu diperlukan gaya kepemimpinan transformasional dalam pengelolaan PDAM. Beberapa hasil penelitian menyatakan bahwa gaya kepemimpinan transformasional dapat mempengaruhi orientasi pasar (Theodosiou et al., 2012; Pinho et al, 2014; Chiun et al., 2015). Beberapa hasil penelitian menyatakan bahwa orientasi pasar dapat mempengaruhi kinerja perusahaan (Mahmoud et al., 2010; Ahmad, 2011; Chin, 2013; Wilson et al., 2014; Shehu dan Mahmood, 2014), sehingga perusahaan yang ber- 
orientasi pasar akan lebih siap dalam memberikan pelayanan yang berkualitas dan bernilai unggul karena dapat menciptakan kepuasan pelanggan dan orientasi pelanggan (Faryabi et al., 2011; Ramayah et al, 2011; Chin et al., 2013). Oleh karena itu orientasi pasar berpengaruh positif terhadap kualitas pelayanan (Ramayah et al., 2011; Hojati et al., 2012; Chin et al., 2013; Pahi dan Hamid, 2015).

Untuk dapat menciptakan public value, PDAM harus mampu memberikan kualitas pelayanan sesuai dengan harapan pelanggan dikarenakan kualitas pelayanan dapat menciptakan kepuasan pelanggan, oleh karena itu diperlukan pimpinan yang transformational. Beberapa hasil studi menunjukkan bahwa pemimpin transformational dapat meningkatkan pegawai untuk menyampaikan pelayanan terbaik kepada pelanggan (Rowold, 2011; Wright et al., 2012; Pahi dan Hamid, 2015; Lyical dan Celebi,
2016). Hal ini dikarenakan kualitas pelayanan dapat mempengaruhi kinerja perusahaan (Chiun et al., 2015; Kersten dan Koch, 2010).

Rerangka konseptual ini secara keseluruhan menggambarkan pengaruh langsung antara variabel gaya kepemimpinan transformasional terhadap kinerja PDAM Tirta Khatulistiwa Pontianak, gaya kepemimpinan transformasional terhadap orientasi pasar, gaya kepemimpinan transformasional terhadap kualitas pelayanan, selanjutnya orientasi pasar berpengaruh terhadap kinerja PDAM Tirta Khatulistiwa Pontianak, orentasi pasar berpengaruh terhadap kinerja PDAM Tirta Khatulistiwa Pontianak, selanjutnya kualitas layanan berpengaruh pada kinerja PDAM Tirta Khatulistiwa Pontianak. Berdasarkan uraian tersebut, pengaruh antar variabel dalam studi ini secara keseluruhan digambarkan dalam Gambar 1.

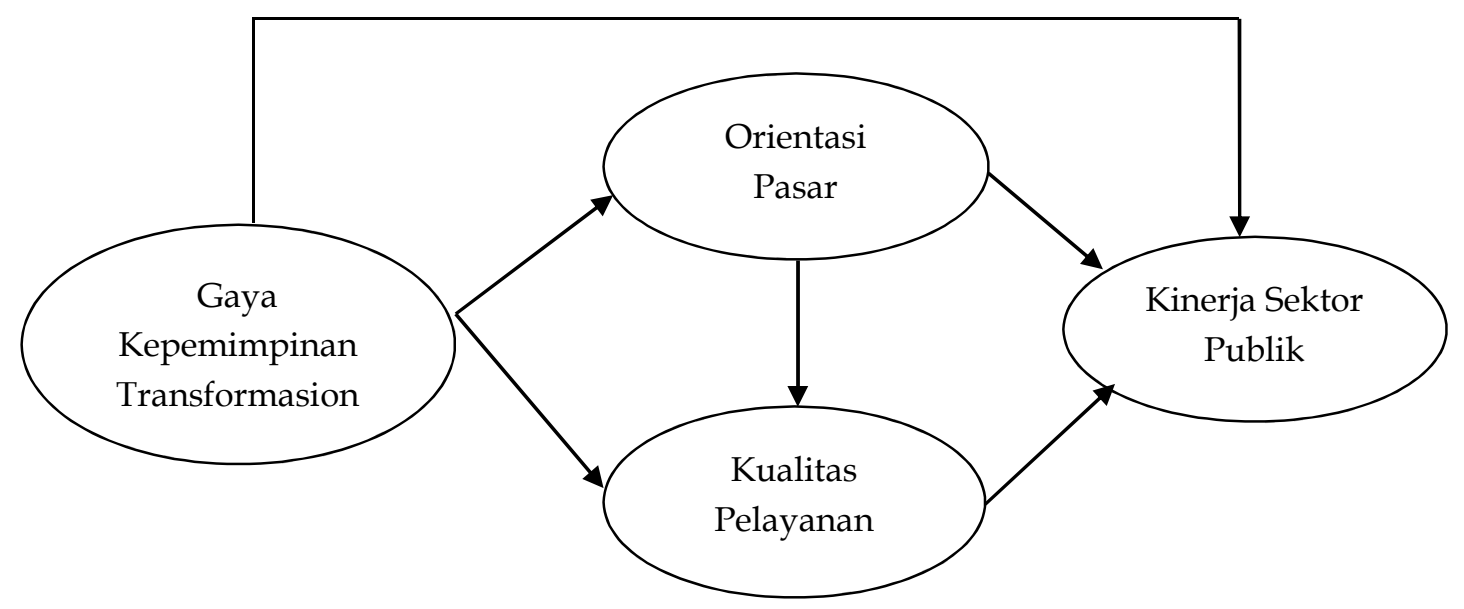

Gambar 1

Rerangka Konseptual Penelitian

\section{METODE PENELITIAN}

Penelitian ini dilakukan pada PDAM Tirta hatulistiwa Pontianak di Kalimantan Barat. Teknik pengambilan data dengan cara menyebarkan kuesioner untuk masingmasing bagian, dengan teknik pengambilan sampel purposive sampling diambil sebanyak 100 karyawan yang terdiri dari kepala bagian, kepala seksi dan karyawan pada bagian yang berhubungan langsung dengan pelayanan (Produksi, Distribusi, Pengendalian Kehilangan Air (PKA), dan Kantor Pelayanan). Dasar pertimbangan yang digunakan dalam pengambilan sampel sebanyak 100 karyawan (Hair et al., 2010), menyatakan bahwa jika sampel diatas 400 akan mengakibatkan fit model (goodness-offit) tidak begitu baik, sehingga lebih di- 
sarankan penggunaan sampel pada selang 100-400. Sehingga alat analisis yang digunakan dalam penelitian ini adalah Structural Equation Modeling (SEM).

Variabel gaya kepemimpinan transformasional dalam penelitian ini mengacu pada konsep Bass dan Avolio), yang dikembangkan dalam sektor publik (Wright, 2012; Oberfield 2012; Donald et al., 2014.), yang meliputi: idealized influence, inspirasional motivation, intellectual stimulation dan individual consideration, sedangkan variabel orientasi pasar menggunakan konsep pengukuran MARKOR yang dikemukanan oleh Kohli dan Jaworski, yang dimodifikasi sesuai dengan konteks sektor publik dengan mengacu pada (Walker et al., 2011; Protco dan Dornberger 2014), diantaranya; intelli- gence dissemination, intelligence generation, dan responsiveness. Untuk variabel kualitas pelayanan mengacu pada konsep Brady dan Cronin, serta dimensi SERVQUAL yang dikembangkan sesuai dengan desain penelitian (Munhurrum, 2010; Foster 2010: 257; Chang dan Horg, 2010; Greenwel et al., 2012; Afifah et al., 2015). Adapun variabel kinerja PDAM dalam penelitian ini mengacu pada pendapat (Ozer dan Tinaztepe, 2014; Madsen dan Stenheim, 2014) yang meliputi; pertumbuhan jumlah pelanggan, kemampuan pengembangan produk/layanan, profitabiltas perusahaan, komitmen karyawan.

Untuk lebih jelasnya definisi operasional variabel dalam penelitan ini dapat dilihat pada Tabel 1.

Tabel 1

Dinisisi Operasional Variabel

\begin{tabular}{|c|c|c|}
\hline Variabel & Indikator & Sumber \\
\hline Gaya & 1. Idealized Influence & Wright, \\
\hline \multirow{8}{*}{$\begin{array}{l}\text { kepemimpinan } \\
\text { transformasional }\end{array}$} & a. Merasa nyaman bila pimpinan berada disekitar kita. & 2012; \\
\hline & b. Mempercayai kemampuan dan kapabilitas pimpinan & Oberfield \\
\hline & dalam menyelesaikan masalah. & 2012; \\
\hline & c. Sangat percaya sepenuhnya kepada pimpinan. & Donald et \\
\hline & 2. Inspirational Motivation. & al., 2014. \\
\hline & $\begin{array}{l}\text { a. Pimpinan meningkatkan optimisme terhadap masa } \\
\text { depan perusahaan. }\end{array}$ & \\
\hline & $\begin{array}{l}\text { b. Pimpinan mendorong untuk sukses dalam suatu } \\
\text { pekerjaan. }\end{array}$ & \\
\hline & c. Pimpinan membuat antusias dalam suatu pekerjaan. & \\
\hline
\end{tabular}

3. Intelectual Stimulation
a. Pimpinan memberikan cara baru dalam menyelesaikan masalah.
b. Pimpinan melihat permasalahan dengan berbagai pandangan.
c. Pimpinan mencari beberapa alternative ketika memecahkan masalah.

4. Individual Consideration
a. Pimpinan memberikan perhatian secara pribadi
b. Pimpinan memperhatikan secara individual
c. Pimpinan siap memberi petunjuk apabila dibutuhkan. 
Orientasi pasar

Kualitas

pelayanan
1. Intelligence Dissemination

a. Rapat antar bagian dilakukan seminggu sekali

b. Komunikasi antar bagian mengenai kebutuhan pelanggan

c. Menyediakan waktu untuk diskusi mengenai kebutuhan pelanggan

2. Intelligence Generation
a. Melakukan survey pelanggan setahun sekali
b. Mencari informasi mengenai perubahan kebutuhan pelanggan
c. Meninjau ulang pengaruh perubahan lingkungan untuk memenuhi kebutuhan pelanggan.

3. Responsiveness.
a. Perhatian terhadap kebutuhan pelanggan
b. Usaha untuk memperbaiki produk/layanan sesuai keinginan pelanggan.
c. Perhatian terhadap keluhan pelanggan

1. Interaction Quality
a. Sikap karyawan
b. Perilaku dan ketrampilan karyawan
c. Keahlian karyawan.

2. Physical Environment Quality
a. Lokasi PDAM
b. Kenyamana tempat pelayanan
c. Fasilitas

3. Outcome Quality.
a. Kecepatan proses
b. Jaminan 3 K (Kualitas, Kontinyuitas dan Kuantitas) air PDAM

Kinerja PDAM. 1. Petumbuhan jumlah pelanggan

2. Kemampuan pengembangan produk/layanan

3. Profitabilitas perusahaan

4. Komitmen karyawan

5. Kepuasan kerja karyawan
Walker et al., 2011; Protco dan Dornberger 2014.
Munhurrum, 2010; Foster 2010: 257; Chang dan Horg, 2010; Greenwel et al., 2012;

Afifah et al., 2015

Ozer dan Tinaztepe (2014); Madsen dan Stenheim, 2014.

\section{ANALISIS DAN PEMBAHASAN}

Untuk mengetahui karakteristik pegawai PDAM Tirta Khatulistiwa Pontianak yang dijadikan responden dalam penelitian ini dapat dilihat pada Tabel 2.

Tabel 2

Karakteristik Responden

\begin{tabular}{clcc}
\hline \hline $\begin{array}{c}\text { Karakteristik } \\
\text { Responden }\end{array}$ & \multicolumn{1}{c}{ Keterangan } & Frekwensi & Persentase (\%) \\
\hline Jenis Kelamin & Laki-laki & 67 & 67 \\
& Perempuan & 33 & 33 \\
Masa Kerja & 1-3 Tahun & 6 & 6 \\
& 3-4 Tahun & 29 & 29 \\
& Diatas 5 Tahun & 65 & 65 \\
Usia & 20 - 24 Tahun & 11 & 11 \\
& 25 -29 Tahun & 23 & 23
\end{tabular}




\begin{tabular}{llcc} 
& $30-34$ Tahun & 29 & 29 \\
\multirow{5}{*}{ Pendidikan } & 35 Ke atas & 37 & 37 \\
& SMA & 32 & 32 \\
& D3 & 21 & 21 \\
& S1 & 41 & 41 \\
& S2 & 6 & 6 \\
\hline
\end{tabular}

Untuk mengetahui deskripsi jawaban responden dalam penelitian ini, dapat dilihat pada Tabel 3.

Tabel 3

Deskripsi Jawaban Responden

\begin{tabular}{|c|c|c|c|c|}
\hline $\begin{array}{l}\text { Item Pertanyaan } \\
\text { Variabel Gaya Kepemimpinan Transformasional }\end{array}$ & Rata-2 & Max & Min & Standar D \\
\hline 1. Merasa nyaman bila pimpinan berada disekitar kita. & 28 & 54 & 13 & 20,5 \\
\hline $\begin{array}{l}\text { 2. Mempercayai kemampuan dan kapabilitas pimpinan } \\
\text { dalam menyelesaikan masalah. }\end{array}$ & 30,333 & 62 & 7 & 27,6 \\
\hline 3. Sangat percaya sepenuhnya kepada pimpinan & 28,933 & 51 & 3 & 25,6 \\
\hline $\begin{array}{l}\text { 4. Pimpinan meningkatkan optimisme terhadap masa } \\
\text { depan perusahaan. }\end{array}$ & 31,933 & 79 & 9 & 17,6 \\
\hline $\begin{array}{l}\text { 5. Pimpinan mendorong untuk sukses dalam suatu } \\
\text { pekerjaan. }\end{array}$ & 26,933 & 42 & 27 & 7,8 \\
\hline 6. Pimpinan membuat antusias dalam suatu pekerjaan & 27,267 & 50 & 9 & 17,7 \\
\hline $\begin{array}{l}\text { 7. Pimpinan memberikan cara baru dalam } \\
\text { menyelesaikan masalah. }\end{array}$ & 29,6 & 56 & 44 & 8,5 \\
\hline $\begin{array}{l}\text { 8. Pimpinan melihat permasalahan dengan berbagai } \\
\text { pandangan. }\end{array}$ & 24,866 & 40 & 5 & 16,1 \\
\hline $\begin{array}{l}\text { 9. Pimpinan mencari beberapa alternative ketika } \\
\text { memecahkan masalah }\end{array}$ & 29,4 & 55 & 14 & 20,6 \\
\hline 10. Pimpinan memberikan perhatian secara pribadi & 30,866 & 63 & 37 & 18,4 \\
\hline 11. Pimpinan memperhatikan secara individual & 21,8 & 28 & 5 & 9,6 \\
\hline $\begin{array}{l}\text { 12. Pimpinan siap memberi petunjuk apabila } \\
\text { dibutuhkan }\end{array}$ & 27,867 & 41 & 23 & 9,3 \\
\hline \multicolumn{5}{|l|}{ Variabel Orientasi Pasar } \\
\hline 1. Rapat antar bagian dilakukan seminggu sekali & 26,8 & 73 & 2 & 32,7 \\
\hline $\begin{array}{l}\text { 2. Komunikasi antar bagian mengenai kebutuhan } \\
\text { pelanggan }\end{array}$ & 24,2 & 35 & 8 & 11,9 \\
\hline $\begin{array}{l}\text { 3. Menyediakan waktu untuk diskusi mengenai } \\
\text { kebutuhan pelanggan }\end{array}$ & 26,13 & 39 & 9 & 12,5 \\
\hline 4. Melakukan survey pelanggan setahun sekali & 28,4 & 50 & 5 & 19,8 \\
\hline $\begin{array}{l}\text { 5. Mencari informasi mengenai perubahan kebutuhan } \\
\text { pelanggan }\end{array}$ & 21,13 & 27 & 9 & 7,4 \\
\hline $\begin{array}{l}\text { 6. Meninjau ulang pengaruh perubahan lingkungan } \\
\text { untuk memenuhi kebutuhan pelanggan }\end{array}$ & 27,06 & 43 & 3 & 17,2 \\
\hline 7. Perhatian terhadap kebutuhan pelanggan & 27,46 & 42 & 8 & 17,9 \\
\hline $\begin{array}{l}\text { 8. Usaha untuk memperbaiki produk/layanan sesuai } \\
\text { keinginan pelanggan. }\end{array}$ & 24,86 & 40 & 14 & 10,98 \\
\hline \multirow{2}{*}{\multicolumn{5}{|c|}{ Variabel Kualitas Pelayanan }} \\
\hline & & & & \\
\hline 1. Sikap karyawan & 25,266 & 38 & 17 & 9,27 \\
\hline 2. Perilaku dan ketrampilan karyawan & 27,133 & 39 & 5 & 15,12 \\
\hline 3. Keahlian karyawan. & 27,666 & 43 & 8 & 18,56 \\
\hline
\end{tabular}


14 Ekuitas: Jurnal Ekonomi dan Keuangan - Volume 1, Nomor 1, Maret 2017 : 1 - 23

4. Lokasi PDAM

5. Kenyamana tempat pelayanan

6. Fasilitas

7. Kecepatan proses

8. Jaminan $3 \mathrm{~K}$ (Kualitas, Kontinyuitas dan Kuantitas) air PDAM

Variabel Kinerja PDAM

1. Petumbuhan jumlah pelanggan

2. Kemampuan pengembangan produk/layanan

3. Profitabilitas perusahaan

4. Komitmen karyawan

5. Kepuasan kerja karyawan

$\begin{array}{llll}25,533 & 39 & 7 & 13,8 \\ 28,266 & 46 & 22 & 12,05 \\ 26,93 & 59 & 5 & 22,09 \\ 25,6 & 41 & 3 & 16,19 \\ 25,066 & 32 & 5 & 13,07\end{array}$

$\begin{array}{llll}29,266 & 51 & 12 & 19,7 \\ 24,4 & 34 & 11 & 9,89 \\ 25,466 & 53 & 9 & 18,7 \\ 27,266 & 41 & 5 & 15,42 \\ 25,733 & 37 & 5 & 14,05\end{array}$

Hasil pengujian antar variabel dalam penelitian ini, secara rinci dapat dilihat pada Tabel 4. variabel, hipotesis dalam penelitian ini akan diterima apabila nilai a lebih kecil dari 0,05.

Tabel 4

Hasil Pengujian Hipotesis

\begin{tabular}{|c|c|c|c|c|}
\hline Variabel & $\begin{array}{l}\text { Koefi- } \\
\text { sien }\end{array}$ & C.R. & Prob. & Keterangan \\
\hline $\begin{array}{l}\text { Gaya kepemimpinan transformasional } \rightarrow \text { Kinerja Sektor } \\
\text { Publik }\end{array}$ & 0,426 & 5,128 & 0,000 & Signifikan \\
\hline $\begin{array}{l}\text { Gaya kepemimpinan transformasional } \rightarrow \text { Orientasi } \\
\text { pasar }\end{array}$ & 0,144 & 2,009 & 0,045 & Signifikan \\
\hline $\begin{array}{l}\text { Gaya kepemimpinan transformational } \rightarrow \text { Kualitas } \\
\text { pelayanan }\end{array}$ & 0,121 & 1,595 & 0,124 & $\begin{array}{l}\text { Tidak } \\
\text { Signifikan }\end{array}$ \\
\hline Orientasi pasar $\rightarrow$ Kualitas pelayanan & 0,324 & 1,578 & 0,115 & $\begin{array}{l}\text { Tidak } \\
\text { Signifikan }\end{array}$ \\
\hline Orintasi pasar $\rightarrow$ Kinerja Sektor Publik & 0,411 & 4,899 & 0,000 & Signifikan \\
\hline Kualitas pelayanan $\rightarrow$ Kinerja Sektor Publik & 0,315 & 2,835 & 0,004 & Signifikan \\
\hline
\end{tabular}

Berdasarkan Tabel 4, interpretasi masingmasing koefisien jalur adalah sebagai berikut:

Hipotesis 1 : Gaya kepemimpinan transformasional berpengaruh positif terhadap kinerja PDAM Tirta Khatulistiwa Pontianak.

Hasil pengujian koefisien jalur (Tabel 4) menunjukkan bahwa gaya kepemimpinan transformasional berpengaruh positif terhadap kinerja PDAM Tirta Khatulistiwa Pontianak dengan arah positif sebesar 0,426 dengan nilai C.R. sebesar 5,128 dan diperoleh probabilitas signifikansi $(p)$ sebesar 0,000 yang lebih kecil dari taraf signifikansi $(\alpha)$ yang ditentukan sebesar 0,000 . Hal ini berarti bahwa hipotesis pertama dalam studi ini yang menyatakan bahwa gaya ke- pemimpinan transformasional berpengaruh positif terhadap kinerja PDAM Tirta Khatulistiwa Pontianak, terbukti kebenarannya.

Diterimanya Hipotesa 1, menunjukkan bahwa gaya kepemimpinan yang ada dilingkungan PDAM Tirta Khatulistiwa Pontianak dalam memimpin perusahaan adalah dengan menggunakan gaya kepemimpinan transformasional, sehingga mereka memiliki kemampuan untuk menginspirasi, memotivasi dan mempengaruhi seluruh pegawai di lingkungan PDAM untuk mencapai visi dan misi organisasi sehingga kinerja PDAM sebagai public value semakin membaik mulai dari tahun 2011 sampai dengan saat ini, dimana kondisi PDAM mendapatkan penilaiain kinerja 
coorporate dengan kategori "sehat". Penilaian dilakukan oleh BPKP Perwakilan yang ada di Propinsi Kalbar diantaranya kategori sehat, kurang sehat dan sakit. Hal ini menunjukkan Pimpinan PDAM Tirta Khatulistiwa mampu mengoptimalkan sumber daya manusia yang dimiliki untuk menjalankan misi dan visi yang sudah ditetapkan. Selain itu beberapa hasil diskripsi jawaban responden dalam indikator idealized influence menyatakan bahwa rata-rata sangat baik, begitu juga dengan inspirational motivation, intellectual stimulation serta individual consideration, rata-rata jawaban responden dalam penelitian ini menyatakan sangat baik, dengan demikian bahwa gaya kepemimpinan transformasional sangat mempengaruhi pegawai dalam mencapai kinerja yang menjadi tanggung jawabnya.

Hasil penelitian ini sependapat dengan hasil penelitian (Peris dan Namusonge, 2012; Donald et al., 2014; Ozer dan Tinaztepe, 2014; Birasnav, 2014; Chiun et al., 2015), yang menyatakan bahwa gaya kepemimpinan transformasional berpengaruh pada kinerja perusahaan.

Hipotesis 2 : Gaya kepemimpinan transformasional berpengaruh positif terhadap orientasi pasar.

Hasil pengujian koefisien jalur (Tabel 4) menunjukkan bahwa gaya kepemimpinan berpengaruh terhadap orientasi pasar dengan arah positif. Hal ini terlihat dari jalur yang bertanda positif sebesar 0,144 dengan nilai C.R. sebesar 2,009 dan diperoleh probabilitas signifikansi (p) sebesar 0,045 yang lebih kecil dari taraf signifikansi $(\alpha)$ yang ditentukan sebesar 0,05 . Hal ini berarti bahwa hipotesis ke dua dalam studi ini yang menyatakan bahwa gaya kepemimpinan transformasional berpengaruh positif terhadap orientasi pasar, dalam hal ini adalah PDAM Tirta Khatulistiwa Pontianak terbukti kebenarannya. Diterimanya $\mathrm{H}_{2}$, menunjukkan bahwa Pimpinan PDAM Tirta Khatulistiwa Pontianak menetapkan misi dan visi PDAM yang berorientasi kepada pelanggan di karenakan Pimpinan menyadari bahwa
PDAM merupakan sektor publik yang harus menciptakan public value, dengan penekanan pelanggan di pusat strategi dan operasi perusahaan selain itu terus berupaya untuk meningkatkan hubungan antar bagian dalam meningkatkan kinerja pelayanan. Hal ini dibuktikan pada saat ini PDAM Tirta Khatulistiwa untuk meningkatkan pelayanan kepada masyarkat terus menerus dengan melakukan perbaikan terhadap kualitas, kuantitas dan kontinuitas pelayanan air kepada masyarakat sesuai dengan peraturan Menkes yang mengacu pada standar air minum, sehingga selalu berusaha untuk memperbaiki produk/layanan yang ada, selain itu untuk proses pengaduan serta pemasangan sambungan telah diberlakukan pelayanan on line yang bisa diakses oleh pelanggan (Afifah dan Afandi, 2015: Afifah et al., 2015), dengan demikian orientasi pasar yang ditetapkan di PDAM Tirta Khatulistiwa sudah di sesuaikan dengan pelanggan PDAM Tirta Khatulistiwa Pontianak.

Berdasarkan hasil jawaban responden dari indikator oreintasi pasar, diantaranya intelligance dissemination, intelligance generation, serta responsiveness rata-rata penilaian responden menyatakan baik. Hal ini menunjukkan bahwa oreintasi pasar yang dilakukan oleh PDAM Tirta Khatulistiwa sudah sesuai dengan kebutuhan pelanggan, dimana setiap tahun dilakukan survey kepuasan pelanggan, selalu mencari informasi mengenai perubahan kebutuhan pelanggan, selalu memperbaiki produk/ layanan yang diberikan oleh PDAM dalam hal 3K (kualitas, kuantitas, kontinyuitas air), serta setiap minggu sekali pimpinan PDAM melakukan komunikasi (rapat) antar bagian dalam rangka meningkatkan kinerja pelayanan kepada pelanggan.

Diterimanya hipotesa ini, menjelaskan bahwa gaya kepemimpinan yang dilakukan oleh pimpinan PDAM Tirta Khatulistiwa mampu menciptakan orientasi pasar yang kuat, dan ini sangat dibutuhkan dalam manajemen sektor publik dikarenakan 
berada pada lingkungan yang komplek dan turbulence (Pandey 2010; Donald et al., 2014) dan yang berorientasi pasar (Mahmoud et al., 2010; Gummerus, 2013: Rubina et al., 2016), dikarenakan dengan oreintasi pasar, perusahaan akan mencari sumber informasi yang ada di lingkungan eksternal untuk menjalin hubungan dengan pelanggan dan memahami kebutuhan dan keinginan pelanggan, sehingga dengan orientasi pasar yang kuat, PDAM dapat menciptakan kualitas pelayanan kepada pelanggan.

Hasil penelitian ini sependapat dengan (Theodosiou et al., 2012; Pinho et al, 2014; Chiun et al., 2015), yang menyatakan bahwa gaya kepemimpinan transformasional berpengaruh terhadap oreintasi pasar.

Hipotesis 3 : Gaya kepemimpinan transformasional berpengaruh positif terhadap kualitas layanan.

Hasil pengujian koefisien jalur (Tabel 4) menunjukkan bahwa gaya kepemimpinan tidak berpengaruh positif terhadap kualitas pelayanan. Hal ini terlihat dari jalur yang bertanda positif sebesar 0,121 dengan nilai C.R. sebesar 1,595 dan diperoleh probabilitas signifikansi (p) sebesar 0,124. Hal ini berarti bahwa hipotesis ke tiga dalam studi ini yang menyatakan bahwa gaya kepemimpinan transformasional berpengaruh positif terhadap kualitas layanan, dalam hal ini adalah PDAM Tirta Khatulistiwa Pontianak tidak terbukti kebenarannya.

Kualitas layanan sebagai salah satu strategi kompetitif yang sangat penting untuk meningkatkan profitabilitas perusahaan dan kelangsungan hidup perusahaan. Kualitas layanan lebih sulit dievaluasi oleh pelanggan dari pada kualitas barang, dikarenakan penilaian terhadap kualitas layanan tidak hanya didasarkan pada hasil kualitas dari teknik layanan saja tetapi melibatkan proses penyediaan layanan atau kualitas fungsional (Lovelock, 2012). Tidak berpengaruhnya gaya kepemimpinan transformasional terhadap kualitas pelayanan (Hipotesa 3), hal ini dikarenakan konsep orientasi pasar yang ada tidak dibarengi dengan penyesuaian terhadap sumber daya yang dimiliki dan proses bisnis perusahaan, sehingga pegawai pelayanan PDAM belum sepenuhnya menghantarkan kualitas pelayanan yang sudah ditetapkan dalam orientasi pasar, oleh karena itu, pada tingkatan organisasi manajemen puncak harus selalu menekankan dan memberikan pelatihan kepada pegawai untuk memastikan bahwa pegawai selalu menempatkan pelanggan sebagai prioritas pertama dan berusaha memenuhi kebutuhan pelanggan dengan cara yang paling tepat.

Hasil penelitian ini tidak sependapat dengan (Rowold, 2011; Wright et al., 2012; Pahi dan Hamid, 2015; Lyical dan Celebi, 2016), yang menyatakan bahwa pemimpin transformasional dapat meningkatkan pegawai untuk menyampaikan pelayanan terbaik kepada pelanggan.

Hipotesis 4 : Orientasi pasar berpengaruh positif terhadap kualitas layanan.

Hasil pengujian koefisien jalur (Tabel 4) menunjukkan bahwa orientasi pasar tidak berpengaruh terhadap kualitas pelayanan. Hal ini terlihat dari jalur yang bertanda positif sebesar 0,324 dengan nilai C.R. sebesar 1,658 dan diperoleh signifikansi (p) sebesar 0,155 . Hal ini berarti bahwa hipotesis ke empat dalam studi ini yang menyatakan bahwa orientasi pasar berpengaruh positif terhadap kualitas layanan, dalam hal ini adalah PDAM Tirta Khatulistiwa Pontianak tidak terbukti kebenarannya.

Tidak diterimanya $\mathrm{H}_{4}$, mengidentifikasikan bahwa kualitas layanan yang dikembangkan dan dijalankan oleh PDAM bisa jadi tidak didasarkan pada konsep orientasi pasar yang cukup kuat, dikarenakan adanya kekurangan sumber daya yang ada di PDAM Tirta Khatulistiwa Pontianak Kalimantan Barat, sehingga tidak berpengaruhnya orientasi pasar terhadap kualitas pelayanan karena masih banyak pegawai yang tidak memahami orientasi pasar dan merasa bahwa orientasi pasar adalah tanggung jawab organisasi secara ke- 
seluruhan, bukan merupakan proses terintegrasi antar bagian dan jelas pengukurannya. Sehingga pegawai belum memiliki kesadaran secara keseluruhan terhadap penyampaian layanan yang berkualitas sesuai dengan tanggung jawab sektor publik yaitu menciptakan public value kepada masyarakat (pelanggan).

Oleh karena itu agar konsep orientasi pasar yang sudah ditetapkan oleh PDAM Tirta Khatulistiwa Pontianak agar dapat mempengaruhi perilaku pegawai dalam memberikan pelayanan kepada pelanggan, maka diharapkan pimpinan PDAM Tirta Khatulistiwa mengaplikasikan oreintasi pasar dalam dua pendekatan sekaligus, baik pendekatan budaya maupun perilaku. Konsep orientasi pasar dibedakan menjadi dua, yaitu (1) Pendekatan budaya yang menyatakan bahwa orientasi pasar merupakan serangkaian kegiatan yang menekankan pada nilai-nilai bersama perusahaan dan menganggap bahwa pelanggan adalah prioritas pertama, (2) Pendekatan perilaku yang menyatakan bahwa orientasi pasar merupakan serangkaian kegiatan yang diarahkan untuk membuat pelanggan senang (Zafar et al., 2016).

Hasil penelitian ini tidak sependapat dengan hasil penelitian (Ramayah et al., 2011; Hojati et al., 2012; Chin et al., 2013; Pahi dan Hamid, 2015), yang menyatakan bahwa orientasi pasar berpengaruh positif terhadap kualitas pelayanan.

Hipotesis 5 : Orientasi pasar berpengaruh positif terhadap kinerja PDAM Tirta Khatulistiwa Pontianak.

Hasil pengujian koefisien jalur (Tabel 4) menunjukkan bahwa orientasi pasar berpengaruh terhadap kinerja PDAM Tirta Khatulistiwa Pontianak dengan arah positif. Hal ini terlihat dari jalur yang bertanda positif sebesar 0,411 dengan nilai C.R. sebesar 4,899 dan diperoleh signifikansi (p) sebesar 0,000 . Hal ini berarti bahwa hipotesis ke lima dalam studi ini yang menyatakan bahwa orientasi pasar berpengaruh positif terhadap kinerja perusahaan, dalam hal ini adalah PDAM Tirta Khatulistiwa Pontianak terbukti kebenarannya.

Diterimanya $\mathrm{H}_{5}$, menunjukkan bahwa orientasi pasar yang semakin kuat akan semakin memahami akan kebutuhan pelanggan. Hal ini dibuktikan dengan adanya perbaikan secara terus menerus dilakukan oleh PDAM dalam hal penyampaian produk/layanan kepada pelanggan dalam hal 3K (kualitas, kuantitas dan kontinyuitas air), selain itu dalam hal proses pengaduan serta proses-proses yang lainnya seperti proses pemasangan SR Baru, PDAM Tirta Khatulistiwa memberikan pelayanan kepada pelanggan dengan menetapkan standar pelayanan yang cepat dan tepat serta bisa langsung di akses secara online, sehingga secara keseluruhan pimpinan PDAM Tirta Khatulistiwa Pontianak telah menetapkan orientasi pasar yang tertuang dalam misi dan visi organisasi.

Hasil penelitian ini, sejalan dengan beberapa hasil penelitian yang dilakukan oleh (Mahmoud et al., 2010; Ahmad, 2011; Chin, 2013; Wilson et al., 2014; Shehu dan Mahmood, 2014).

Hipotesis 6 : Kualitas pelayanan berpengaruh positif terhadap kinerja PDAM Tirta Khatulistiwa Pontianak.

Hasil pengujian koefisien jalur (Tabel 4) menunjukkan bahwa kualitas pelayanan berpengaruh terhadap kinerja PDAM Tirta Khatulistiwa Pontianak dengan arah positif. Hal ini terlihat dari jalur yang bertanda positif sebesar 0,315 dengan nilai C.R sebesar 2,835 dan diperoleh signifikansi ( $p$ ) sebesar 0,004 . Hal ini berarti bahwa hipotesis ke enam dalam studi ini yang menyatakan bahwa kualitas pelayanan berpengaruh positif terhadap kinerja sektor publik, dalam hal ini adalah PDAM Tirta Khatulistiwa Pontianak terbukti kebenarannya.

Diterimanya $\mathrm{H}_{6}$, menunjukkan bahwa kualitas pelayanan yang dilakukan oleh pegawai PDAM Tirta Khatulistiwa Pontianak dalam hal ini diantaranya hubungan interaksi antara pegawai dengan pelanggan 
sudah dilakukan dengan baik, pegawai melakukan proses pelayanan sesuai dengan harapan pelanggan sehingga hal ini menjadikan kinerja perusahaan meningkat. Hal ini dibuktikan dengan jumlah pelanggan yang semakin meningkat serta kinerja keuangan yang semakin membaik. Hanya saja dalam penelitian ini kualitas pelayanan adalah bersifat internal bukan karena persepsi pelanggan, sehingga kinerja perusahaan dalam hal ini adalah dilihat dari sudut internal.

Hasil penelitian ini sependapat dengan (Kersten dan Koch, 2010; Shekarchizadeh et al., 2011; Chiun et al., 2015), yang menyatakan bahwa kualitas pelayanan dapat mempengaruhi kinerja perusahaan.

\section{SIMPULAN DAN SARAN Simpulan}

Gaya kepemimpinan transformasional berpengaruh signifikan terhadap kinerja sektor PDAM Tirta Khatulistiwa Pontianak Kalbar, dan berpengaruh signifikan terhadap orientasi pasar dengan arah hubungan positif, akan tetapi tidak berpengaruh terhadap kualitas pelayanan. Dengan tidak berpengaruhnya gaya kepemimpina transformasional terhadap kualitas pelayanan, maka yang perlu diperhatikan dan dilaksanakan di PDAM Tirta Khatulistiwa adalah pimpinan harus mampu dan mengoptimalkan sumber strategis yang dimiliki (Bekkers et al, 2013; Pee dan Kankanhalli. 2015), hal ini sesuai dengan Pendekatan resources base view (RBV) dikemukakan oleh Jay Barney, oleh karena itu kunci keberhasilan organisasi publik adalah membangun strategi berbasis sumber daya (resources base view- RBV) yang dimiliki oleh organisasi untuk memenuhi kebutuhan pelanggan (orientasi pelanggan) dan pemangku kepentingan (stakeholder).

Orientasi pasar tidak berpengaruh signifikan terhadap kualitas pelayanan akan tetapi berpengaruh pada kinerja sektor publik, sedangkan kualitas pelayanan berpengaruh terhadap kinerja sektor publik. Hal ini mengidentifikasikan bahwa kualitas layanan yang dikembangkan dan dijalankan oleh PDAM Tirta Khatulistiwa Pontianak Kalbar bisa jadi tidak didasarkan pada konsep orientasi pasar yang cukup kuat, dikarenakan adanya kekurangan sumber daya yang ada di PDAM Tirta Khatulistiwa Pontianak Kalimantan Barat, oleh karena itu orientasi pasar sangat diperlukan dalam sektor publik karena dengan orientasi pasar yang kuat akan menghasilkan nilai pelanggan yang unggul melalui kualitas layanan yang disampaikan kepada pelanggan sehingga berdampak pada kinerja perusahaan (Mahmoud et al., 2010; Gummerus, 2013: Rubina et al., 2016). Hal ini dikarenakan perkembangan pesat terjadi pada sektor jasa dalam beberapa dekade terakhir di negara-negara maju dan juga negara-negara berkembang, baik pada jasa profit maupun nonprofit berkembang sangat pesat bahkan menjadi sumber pendapatan domestik bruto bagi suatu negara (Lovelock, 2012), dengan demikian yang perlu dilakukan oleh PDAM Tirta Khatulistiwa Pontianak dalam melakukan orientasi pasar harusnya dibarengi dengan penyesuaian terhadap sumber daya yang dimiliki dan proses bisnis perusahaan, sehingga berdampak pada kualitas pelayanan.

\section{Keterbatasan Penelitian}

Penelitian ini hanya menggunakan 100 pegawai sebagai sampel, selanjutnya tidak mempertimbangkan variabel orientasi pasar dan kualitas pelayanan sebagai variabel moderating, sehingga dalam penelitian ini hanya ada pengaruh langsung dan tidak ada pengaruh tidak langsung.

\section{Saran}

Model teoritik yang dikembangkan masih dapat diperluas dengan memasukkan kontruk-konstruk lain seperti budaya kerja, komitmen pegawai, dan inovasi layanan dengan demikian akan didapatkan suatu model yang lebih komprehensif. Penelitian lebih lanjut tentang gaya kepemimpinan transformasional dan transaksional di segala tingkatan manajemen, hal ini dikarenakan 
gaya kepemimpinan transformational dan transaksionl mempengaruhi orientasi pasar yang memang diperlukan dalam sektor publik dalam hal ini adalah PDAM. Selain itu perlu juga melakukan penelitian lebih lanjut tentang orientasi pasar yang dihubungkan dengan budaya orgnisasi kaitannya dengan kualitas layanan.

\section{DAFTAR PUSTAKA}

Agbor M. J. 2011. The Relationship between Customer Satisfaction and Service Quality: a study of three Service sectors in Umea, Umea University.

Afifah, N. dan A. Asnan. 2015. The Impact of CSR, Service Experience, and Interculture Competance on Customer Company Identification, Customer Satisfaction on Customer Loyalty (Case Study: PDAM Tirta Khtulistiwa Pontianak). Procedia Sosial and Behavioural Sciences 211: 277-284.

Afifah, N. S. A. dan I. Daud. 2015. Perception on The Service Experience: An Exploration of Public Sector in PDAM Tirta Khatulistiwa Pontianak West Kalimantan Using Reportary Grid Technique. Global Journal of Business and Sosial Review 4(1): 80-88.

Ahmad, S. 2011. Market Orientation in Pakistan Companies. Pakistan Business Review 106-131. Retrieved from http:// www.iobm.edu.pk/PBR/PBR_1104/11 0407_106-126.pdf.

Asgari, M. R. 2014. The Effect of Leadership Styles on Employees Commitment to Services Quality in Bank Melli Branches of Isfahan. Kuwait chapter of the Arabian Journal of Business and Management Review 3(12): 113.

Babin, B. J. dan K. W. James. 2010. A Brief Retrospective and Introspective on Value. European Business Review 22(5): 471-78.

Bekkers, V. J. J. M., L. G. Tummers., B. G Stuijfzand, dan W. Voorberg. 2013. Social Innovation in the Public Sector: An integrative framework. LIPSE
Working papers 1 (Rotterdam: Erasmus University Rotterdam).

Belle, N. 2013. Leading to Make a Difference: A Field Experiment on the Performnace Effect of Transformational Leadership, Perceived Social Impact and Public Service. Journal of Public Administration Research and Theory. DOI: 10.1093/ jopart/mut 003.

Birasnav, M. 2014. Knowledge Management and Organizational Performance in The Service Industry: The Role of Transformational Leadership Beyond The Effects of Transactional Leadership. Journal of Business Research 67(8): 1622-1629. http://dx.doi.org/10.1016/j.jbusres.201 3.09.006. Diakses 12 September 2016.

BPPSPAM. 2015. Kinerja Penilain PDAM. Kementrian Pekerjaan Umum.

Caemmerer, B., A. Wilson. 2011. An Exploration of the Service Orientation Discrepancy Phenomenon in a Public Sector Context. The Service Industries Journal 31(3): 355-370.

Changa, Y. T. dan C. S. Horng. 2010. Conceptualizing and Measuring experience quality: the customer's perspective. The Service Industries Journal 30(14): 24012419.

Chiun, L. M., A. A. Mohamad., T. Ramayah. Dan W. Y. Chai. 2015. Examining the Effectsof Leadership, Market Orientationand Leader Member Exchange (LMX) on Organisational Performance. Inzinerine Ekonomika-Engineering Economics 26(4): 409-421.

Chin, C. H., Lo May-Chiun dan T. Ramayat. 2013. Market Orientation and Organizational Performance: The Moderating Role of Service Quality. SAGE Article DOI: 10. 1177.

Chung, J. E., Y. Huang., B. Jin dan B. Sternquist. 2011. The Impact of Market Orientation on Chinese retailers' channel relationships. Journal of Business and Industrial Marketing, 26(1): 1425. http://dx.doi.org/10.1108/ 088586.

Crook, T. R., S. Y. Todd., J. G. Combs., D. J. Woehr dan D. J. Ketchen Jr. 2011. 
Does Human Capital Matter? A Metaanalysis of the Rrelationship Between Human Capital and Firm Performance. Journal of applied psychology 96(3): $443 . \quad$ http://dx.doi.org/10.1037/ a0022147.

De Farias, S. A. 2010. Internal Marketing (IM): a Literature Review and Research Propositions for Service Excellence. Brazilian Business Review 7(2): 99-115.

Donal, P. M., K. P. Sanjay dan E. W. Bradley. 2014. Transformational Leadership in the Public Sector: Empirical Evidence of its Effects. https://www.researchgate. net/publication/277224792.

Eris, E. D., dan N. T. Ozmen. 2012. The Effect of Market Orientation, Learning Orientation and Innovativeness on Firm Perfor- mance: A Research from Turkish Logistics Sector. International Journal of Economics Sciences and Applied Research 5: 77-108.

Faryabi, M., R. Tajvidi dan M. Tajvidi. 2011. Investigate the Rrelationship Bbetween Market Orientation and Competitive Advantage in the Iran Tractor Manufacturing Industries. Iranian Journal of Farasoye Modiriat 5(17): 131-160.

Fitriyani, D., W. Tiswiyanti dan E. Prasetyo. 2015. Praktik Good Corporate Governance dan Dampaknya Terhadap Kinerja Berdasarkan Balances Scorecard Pada Perusahaan Daerah Air Minum. Conference in Business, Accounting and Management 2(1).

Frączkiwicz-Wronka A., K. Szymaniec. 2013. Zastosowanie koncepcji RBV do Pragmatyki Funkcjonowania Szpitali Publicznych, Organizacjai Kierowanie"nr5.

Foster, S. T. 2013. Managing Quality: Integrating the Supply Chain. $5^{\text {th }}$ ed. Edinburgh Gate, Harlow: Pearson Education

Grant, A. M. 2012. Leading With Meaning: Eneficiary Contact, Prosocial Im-pact and the Performance Effect of Transformational Leadership. Academy of Management Journal 55: 458-76.
Garcia-Morales, V. J., Jimenez-Barrionuevo, M. M., dan Gutierrez-Gutierrez, L. 2012. Transformational Leadership Influence on Organizational Performance Through Organizational Learning and Innovation. Journal of Business Research 65: 1040-1050. http://dx.doi.org/ 10.1016/j.jbusres.2011.03.005

Greenwell, T., Christopher., S. Janet, Fink, dan L. P. Donna. 2012. Perceptions of the Service Experience: Using Demographic and Psychographic Variables to Identify Customer Segments. Sport Marketing Quarterly 11(4).

Gummerus, J. 2013. Value Creation Processes and Value Outcomes in Marketing Theory: Strangers or Siblings? Marketing Theory 13(1): 19-46.

Hair, J. F. Anderson. 2010. Multivariate Data Analysis. Pearson International Edition.

Hanzaee, K. H., S. Nayabzadeh dan M. Jalaly. 2012. The Effect of Market Orientation, Innovation and Customer Loyalty of Firm's Performance: A Case Study of Islamic Clothing Manufacturing Company. Journal of Basic and Applied Scientific Research 2: 3225-3234.

Hojati, E., A. Shahin dan H. Shirouyehzad. 2012. Prioritization of Service Quality Dimension and Performance Indicators Using Analytic Network Process With the Approach of Balanced Score Card: A Case Study. Interdisciplinary Journal of Contemporary Research in Business 3: 1190-1198.

Irfan, S. M., dan A. Ijaz. 2011. Comparison of Service Quality Between Private and Public Hospitals: Empirical Evidences From Pakistan. Journal of Quality and Technology Management 7(1):1-22.

Isett, K. R., S. A. M. Glied., M. S. Sparer dan L. D. Brown. 2012. When Change Becomes Transformation: A Case Study of Change Management in Medicaid Offices in New York City. Public Management Review 15(1): 1-17.

Kersten, W., dan J. Koch. 2010. The Effect of Quality Management on The Service Quality and Business Success of 
Logisticsser Vice Providers. Internati onal Journal of Quality $\mathcal{E}$ Reliability Management 27: 185-200.

Kumar, K., R. Subramanian dan K. Strandholm. 2011. Market Orientation and Performance: Does Organizational Strategy Matter?. Journal of Applied Business Research 18(1): 37-49.

Kumasey A., S. 2014. Service Quality and Customer Satisfaction: Empirical Evidence from the Ghanaian Public Service. European Journal of Business and Management 6(6).

Lopez, M. B. 2010. Market Orientation, Service Quality and Business Performance of Hotels in Klang Valley of Malaysia (Unpublished master's thesis). Faculty of Hotel \& Tourism Management, Universiti Teknologi Mara, Malaysia.

Lovelock. 2012. Market Orientation and Business Performance: a Framework for Services Organization. Thomson, SouthWestern.

Lyikal, O. C. dan A. Celebi. 2016. Investigating A Quality of Services in The Public Sector. Evidance From Northing Cyprus. Journal Economic and Social Development 3(2).

Madsen, D. Ø. dan T. Stenheim. 2014. Perceived Benefitr of Balanced Scorecard Implementation: Some Preliminary Evidance. Problems and Perspective in Management 12(3).

Mahmoud, M. A., Kastner dan J. Yeboah. (2010). Antecedents, Environmental Moderators and Consequences of Market Orientation: a Study of Pharmaceutical Firms in Ghana. Journal of Medical Marketing 10(3): 231-244.

Mahmoud, M. A. 2011. Market Orientation and Business Performance Among SMEs in Ghana. International Business Research 4(1): 241-251.

Mainardes, E. W. dan Cerqueira Alexandre dos Santos. 2014. Measuring The Internal Market Orientation in The Public Sector. Original Scientific Article.
Munhurrun, P. R., S. D. L. Bhiwaje dan P. Naido. 2010. Service Quality in The Public Service. International Journal of Management and Marketing Research 3(1).

Nayebzadeh, S. 2013. Market Orientation: A New Model. Journalof Basic and Applied Scientific Research 3: 472-483.

Nisa, M., R. Sadaf dan M. Zahid. 2012. Patient Satisfaction Survey in an Obstetric and Action Survey in an Obstetrics and Gynecology Ward of a Tertiary Care Hospital and of a Tertiary Care Hospital and of a Tertiary Care Hospital.

Oberfield, Z. M. 2012. Public Management in Time: A Longitudinal Examination of the Full Range of Leadership Theory. Journal of Public Administration Research and Theory. Advance access. doi: 10.1093/jopart/mus060.

Ozer, F. dan C. Tinaztepe. 2014. Effect of Srategic Leadership Styles on Firm Performance: A study in a Turkish SME. Procedia-Social and Behavioral Sciences 150: 778-784.

Pandey, S. K. 2010. Cutback Management and the Paradox of Public Administration. Review 70(4): 564-71.

Pahi, M. H. dan K. A. Hamid. 2015. The Examination of the Influence of Transformational Leadership Over Commitment to Service Quality: A Case of Hospitals of Sindh, Pakistan. Asian Social Science 11(26).

Pandey, S. K. 2010. Cutback Management and the Paradox of Publiceness. Public Administration Review 50(4): 564 -71.

Pee, L. G dan Kankanhalli. 2015. Interactions Among Factors Influencing Knowledge Management in Public Sector Organizations: A resourceBased View. Goverment Information Quartely xxx-xxx.

Peris, M. K. dan G. S. Namusonge. 2012. The Effect of Leadership Styles on Organizational Performance at State Corporations in Kenya. International Journal of Business and Commerce 2(1): 0112. 
Piening, E. P. 2013. Dynamic Capabilities in Public Organizations: A Literature Review and Research Agenda. Public Management Review 15(2): 209-245.

Pinho, J. C., A. P. Rodrigues dan S. Dibb. 2014. The role of Corporate Culture, Market Orientation and Organisational Commitment in Organisational Performance. The Case of Non-profit Organizations. Journal of Management Development 33(4): 374-398. http:// dx.doi.org/10.1108/JMD-03-2013-0036.

Polat, I., dan M. H. Mutlu. 2012. The Impact of Market Orientation, Entrepreneurial Orientation, Environmental Uncertainty and Internationalization Speed of Firm Performance. European Researchers 27(8/2): 1248-1254.

Protco, E. da D. Utz. 2014. The Impact of Market Orientation on Business Performance-the Case of Tatarstan Knowledge-Intensive Companies (Rusia). Problem and Perspective in Management 12(4).

Ramayah, T., N. Samat dan M. C. Lo. 2011. Market orientation, service quality and organizational performance in service organizations in Malaysia. Asia-Pacific Journal of Business Administration 3: 8-27.

Rowold, J. 2011. Relationship Between Leadership Behaviors and Performance: The Moderating Role of Awork Team's Level of Age, Gender, and Cultural Heterogeneity. Leadership \& Organization Development Journal 32(6): 628-647. http://dx.doi.org/10.1108/0143773111 1161094.

Rubina, J., S. A. Mukhta dan M. Rosli. 2016. The Moderating Effect of Environment on The Relationship Between Market Orientation and Business Performance: A Quantitative Approach. IPBJ 8(1): 16-25.

Schneider, S. K., dan W. M. George. 2011. Servant Leadership Versus Transformational Leadership in Voluntary Service Organizations. Leadership and Organization Development Journal 32(1): 60-77. http://dx.doi.org/10.1108/. Diakses tanggal 6 Oktober 2016.
Shehu, A. M. dan R. Mahmood. 2014. An Empirical Analysisi of Market Orientation and Business Performance Relationship in the Context of Developing Economy. International Journal of Academic Researc in Business Social Sceince 4(9): 457-4.

Shekarchizadeh, A., A. Rasli dan H. H. Tat. 2011. SERVQUAL in Malaysian Universities: Perspectives of International Students. Business Process Management Journal 17: 67-81.

Szymaniec-Mlicka K. 2014. Charakterystyka Otoczenia Organizacji Publicznych, Artykuł po Otrzymaniu Pozytywnych Recenzji Oczekuje na Publikacje w Zeszytach Naukowych Politechniki Śląskiej.

Theodosiou, M., J. Kehagias dan E. Katsikea. 2012. Strategic Orientations, Marketing Capabilities and Firm Performance: An Empirical Investigation in the Context of Frontline Managers in Service Organizations. Industrial Marketing Management 41(7): 1058-1070. http:// dx.doi.org/10.1016/j.indmarman 01.001 .

Voet, J. van der., B. S. Kuipers., S. Groeneveld. 2013. Implementing change in public organizations: The relationship between ledhersip and affective commitment to change I a public sector context. Paper presented at the 11th Public Management Research Conference, Madison, Wisconsin June 20-22.

Wijesekara, W. A. D. S., P. A. P. S. Kumara, dan T. S. L. W. Gunawardana. 2014. Impact of Market Orientation and Entrepreneurial Orientation on Performance: A Study of Small and Medium Scale Garment Manufacturers in Sri Lanka. Paper Presented in Proceedings of the 3rd International Conference on Management and Economics, Faculty of Management and Finance, University of Ruhuna, Sri Lanka. Retrieved from http://www.mgt.ruh.ac.lk/ pubs/pdf/ ICME2014_OP_p373.pdf. Diakses tanggal 6 Oktober 2016 
Walker, R. M., G. A. Brewer., G. A. Boyne dan C. N. Avellaneda. 2011. Market Orientation and Public Service Performance: New Public Management Gone Mad?", Public Administration Review 71(5): 707-717.

Weerawit, L. dan P. Vinai. 2014. The Airline Service Quality Affecting Post Purchase Behavioral Intention: Empirical Evidence from the Low Cost Airline Industry. International Journal of Trade, Economics and Finance 5(2).

Wilson, G. A., J. Perepkin., D. D. Zhang dan M. Vachon. 2014. Market Orientation, Alliance Orientation, and the Business Performance in the Biotechnology in Industry. Journal of Commercial Biotechno$\log y$ 20(2): 32-40.
Wright, B., P. M. Donald dan K. P. Sanjay. 2012. Puing the Levers: Leadership, Public Service Motivation and Mission Valance. Public Administration Review 72: 201-15.

Yukl, G. 2010. Leadership in Organizations, 7th ed. Prentice Hall. New Jersey.

Zafar, H., H. H. Mohammad dan N. Mohd., S. Mohd. 2016. Relationship Between Market Oreintation, Organizational Learning, Organizational Culture and Organizational Performnance: Mediating Impact of Innovation. South East Asia Journal of Contemporary Business Economics and Law 9(2): 2289-1560.

Zizlavsky, O. 2014. The Balanced Scorecard: Innovation Performance Measurement and Management Control System. Journal of Technology Management $\mathcal{E}$ Innovation 9(3). 